\title{
Risk management in plant investment decisions: risk typology, dimensions and process
}

\begin{abstract}
Managing risk associated with plant location decisions are growing concern as companies seek to reassure investors about the robustness of their strategies. Little attention has been paid however to the systematic evaluation of risk associated with new plants. This paper investigates risk management practices in plant investment decisions through detailed case investigations in a cross section of industrial businesses at different levels of maturity in order to observe current practices, identify common principles and to synthesis systematic approaches to risk management where appropriate. It identifies key risk categories and dimension of the risk management. It builds on the three key bodies of literature - global manufacturing, investment and risk management
\end{abstract}

Keywords - Plant Investment decision, Global Manufacturing, Investment Decision Making, Risk Categories, Risk Management Process

\section{Introduction}

Risks and their management are often discussed in new plant investment deliberations, but are rarely defined in literature or practice and even more rarely systematically considered. The success or failure of new plant however may well be determined by the accurate and effective identification and management of risk. As manufacturing continues to globalize and restructure the management of risk has become increasingly important. Risk management processes are not well defined in the context of new plant investment where traditional risk management and 
investment theories provide little guidance on the specific risk associated with new plant. This paper explores how plant investment risk management might be effectively identified, evaluated and managed as a basis for more robust strategic and operational practices.

This paper is organize as follows. Section 2 reviews three distinct literature domains with the contexts of plant investment risk management in order to present theoretical foundation for this research. Section 3 presents detail steps of research approach in order to address research question along with with-in-case analysis and cross-case analysis in tables. In Section 4, we describe risk typology, management dimensions and proposes a framework for industrial investment risk management derived from case studies. We conclude in section 5.

\section{Literature Review}

Manufacturing global expansion has been explained from the perspective of product (Parry, 1975; Vernon, 1966), market (Henzler \& Rall, 1986; Porter, 1986) and functions (Eversheim, 1997; Skinner, 1969). New plant investments and factory closures are key elements of manufacturing network reconfiguration to achieve desired capabilities and capacity (DuBois, Toyne, \& Oliff, 1993; Feldmann, Olhager, \& Persson, 2009; Kumar \& Gregory, 2007; Morrison \& Roth, 1993; Porter, 1986; Roth \& Miller, 1992; Shi \& Gregory, 1998). Clearly production network configuration/reconfiguration requires investment (Hayes \& Wheelwright, 1984; Wheelwright, 1978) but research in this area has tended to focus on strategy, capability development, performance measurement and network development with 'risk management' mentioned only casually (Dabhilkar \& Bengtsson, 2008; Hayes \& Wheelwright, 1984; Srai, Bertoncelj, Fleet, \& Gregory, 2010). 
Preliminary observations of risk management research domain, illustrate that a typical risk management framework might have the followings four steps: Identification, Assessment, Administration (mitigation and risk decision area), and Monitoring (Kallman \& Maric, 2004; Merna \& Al-Thani, 2005). However, these basic steps of risk management have been expanded at different levels reflecting the varied contexts in which risks are being managed (Crouhy, Galai, \& Mark, 2006; Kallman \& Maric, 2004). Most of risk management frameworks are focused on the insurance or financial industry (Harrington, Niehaus, \& Harrington, 2003; Head \& Horn I I, 1991; Kallman \& Maric, 2004). There are three major shortcomings of the existing risk management frameworks - conceptual constructs, corporate level focus and missing context of plant location decisions (Kumar \& Gregory, 2011, 2013).

Investment associated theories such as The Efficient Market Hypothesis (EMH) and Portfolio Theory provide the foundations for traditional investment strategy and risk mitigation practices. Efficient Market Hypothesis is primarily related to capital markets and focuses on rigorous information accessibility and analysis to reduce the investment risk (Jagric, Podobnik, \& Kolanovic, 2005). According to portfolio theory, return is always combined with risk (Hagstrom, 1997; Kazlauskiene \& Christaukas, 2007). Net Present Value (NPV) or Discounted Cash flow (DCF) and real options are widely used investment valuation models and also help in quantifying risk in investment projects concisely (Dixit, 1992; Hertz, 1979; Magni, 2002; Pratt \& Hammond II, 1979). There are two additional methods of risk assessment - Capital Asset Pricing Model (CAPM) and Arbitrage Pricing Theory (Dhankar \& Singh, 2005; Mullins Jr, 1982). However, these theories are a small part of the overall management of risk. 


\section{Approach}

The approach adopted in this research was to undertake detailed case investigations, due to the contemporary nature of the research topic, in a cross section of seven industrial businesses at different levels of maturity in order to observe current practices and to seek to synthesize systematic approaches to risk management where appropriate. The unit of analysis is plant investment risk management and the scope of the research is investment decision making process.

Twenty one structured and ethnographic interviews are used to collect data together with confidential documents. The interviews sought to identify risks and plant investment practices explicitly associated with 'risk' and those explicitly associated with reward and then categorized explicit and implicit practices into risk identification, risk assessment, risk administration and risk monitoring. This small number of case companies provided the opportunity for in-depth observation (Voss, Tsikriktsis, \& Frohlich, 2002) and high quality data (Leonard-Barton, 1990) which are essence of a multi-case study design and theory building method (Leonard-Barton, 1990; Meredith, 1998; Voss et al., 2002)

The case study investigative framework is divided into four segments- business analysis, operational analysis, investment analysis, and risk management mapping (Table 2), providing first-hand information on the research topic exploration of new dimensions that emerged during the interview (Burgess, 1984; Yin, 1994).

The cases explored these explicit and implicit risk management practices and draw out generic themes. A structured data structured collection protocol captured relevant data reflecting the 
research scope and the case study representation structure. This protocol included research project description, email, PowerPoint presentations, confidentiality agreement and two semistructured questionnaires.

Multiple sources were used to collect data. At the end of every case study, full report based on the interview data was sent to the concerned companies. Interview data were shared and discussed with industrial experts. Statistical generalizability is not possible in the case study methodology but analytical generalizability can be inferred (Cook \& Campbell, 1979; Yin, 1994). Data Analysis was structured around key concepts derived from the literature. Initially a with-in case analysis was conducted to identify the different sets of risk and risk management practices. Later, a cross-case analysis was adopted to identify similar or differentiating patterns in the data acquired (Miles \& Huberman, 1994). While with-in case analysis identified the unique capabilities of the company's practices, cross-case analysis brought about generalizations in the results. The key data was analysed and presented in the summary table (Table 1 to 6).

'Insert Table 1 here'

'Insert Table 2 here'

'Insert Table 3 here'

'Insert Table 4 here'

'Insert Table 5 here'

'Insert Table 6 here'

\section{Discussions}

\subsection{Plant Investment Risk Sources}


Investment Project Management Risk: It was observed that global manufacturing companies face risks from plant investment project management. Companies A, B, C, D, E, F, and G stated that erroneous valuation is one of the common risks that have negative impact on the value of the investment. The common source of this risk lies in assumptions within the valuation method, in addition to human error (Company B). However, assumptions change over time. The valuation method requires assumptions because of the lack of reliable future data and historical data. Company F raised the question of reliability of projections from volume, cost and capability perspectives. Unreliability of projection can result in overestimation of revenue and underestimation of cost.

Companies mentioned that they had experienced rises in operational infrastructural development cost. Operational development costs increased due to delays in projects, sudden rise in factory construction costs (due to external risks), difficulties in resource acquisition (such as people, raw materials, vehicle availability and warehouse availability), and failure/delay of supporting projects (information technology system, procurement, and human resources).

During company G's Chinese investment, a new plant collapsed of common architecture of plant design and platform when the soil at the location of the plant could not support the weight of the standardized plant structure. This event delayed the investment project and increased the cost of investment. This is an example of how one risk can create another risk. Similarly, delays in investment projects (except in the case of company A) had affected investment expected earnings. 
Companies $\mathrm{F} \& \mathrm{G}$ raised risk issues such as timing of entering the market and timing of reinvestment. Wrong timing can significantly influence investment returns. If an economy slows down during reinvestment and market entry then it can affect production as a result of decrease in sales. Maintaining the product supply during the plant transfer is one the biggest challenges in Greenfield investment. Company G shut down a plant and opened a new one at a different location by transferring machinery and people. The Company could not keep the product supply consistent during the transition and resulted in reduced revenue for a period and loss of market share. Product supply during transition becomes one of the risks in plant transfer investment.

$R \& D$ Risk: New plants are exposed to risks from research and development activities. Companies B \& G experienced risk in transition from New Product Introduction (NPI) to production ramp up of new products in their plant investment projects and in existing operations. It was suggested that making a new product in small quantity is relatively easier than making the same product at mass production level.

Various factors are responsible for the risk of higher NPI time, NPI failures and NPI profitability. For example, mistakes in R\&D, new production issues during adjustment of production process or implementation of new production processes, lack of training for production, unpredictable market, and lack of training of dealers are among those influential factors, stated by companies B, C, D, E, F, and G.

Intellectual Property Right (IPR) leakage risk was explicitly mentioned in the confidential investment project documents of companies B, E, F, and G. This risk exists in global 
manufacturing investment because of variations in IPR protection laws across the world and weak IP regulatory framework in developing and low cost countries, stated by Company B. Technology can minimize the IPR leakage risk. Company G uses digital codified product design that configures the machines in the Chinese plant. Additionally, deployment of new production process technology and higher automation protects the IPR leakage risk in new plant as stated by the company $\mathrm{G}$.

External factors such as changing consumer behavior, inability to understand the market and underperformance of new product in market increases the R\&D related risks. Additionally, company $\mathrm{G}$ had experienced the risk of new technology adoption in production. New technologies are usually adopted to improve efficiency and product. External risks such as disruptive technology risk and high competition may force companies to adopt new technology. However, new technology adoption may increase the cost of operation and might delay or halt production.

Production Risk: Field studies revealed that new plant is exposed to risks from production activities. Shortage of working capital can arise due to unexpectedly large gaps between accounts payable and accounts receivable, can disrupt production as stated by Company A. This risk becomes more severe when external risks (such as economic slowdown) lead to low confidence in financial institutions. Investigated companies mentioned unexpected increase in operational cost as a risk as they had experienced cost increases in their recent investments. 
Production disruption risks can also originate from factory issues and procurement issues. For example, an investment by company C's previous investment is facing capacity imbalance risks in India, Brazil and China. Capacity imbalance risk surfaced due to incorrect forecasting of regional demand before investment. Capacity imbalance leads to lead time risk. Higher lead-time increases the sales and marketing risk. Company A particularly experienced change in labor cost. After their new plant investment in Poland, the country received EU membership. This resulted in Polish labor migration to the Western Europe. The unexpected labor migration increased the labor cost and scarcity of skills. Skill set risk and labor cost risk can even undermine the investment in rare circumstances, for example, company $\mathrm{G}$ had to move back its factory from Poland to Germany.

Companies A, B, and C mentioned lack of skills as risk. One of the problems is finding the right people for the operations in overseas locations. Company G mentioned that they wanted some people who could speak Chinese and know the parent company, when they initiated the investment in China. It was quite difficult to find skilled expats who can work in China. They hired senior managers from the company for Chinese investment, but they returned due to cultural differences. However, they found a solution when they searched their employees' profiles. The company found several Chinese nationals/Chinese race employees in the company. These employees were happy to work in the new Chinese plant.

Low product quality risk and product recall risk are linked to each other. Lack of training and mistakes in sourcing are the main factors that trigger the risk in investment. Company D had to recall product from the Asia Pacific market due to contaminated raw material sourcing from 
China to its new production facility in Indonesia. Company E had to recall its low quality product because of the news that employees were not well trained. In both cases, companies had to suffer by losing revenue and damaging corporate image.

Company $\mathrm{C}$ mentioned that coordination issues between engine and generator assembly plants, sometimes led to production disruption risk in its new assembly plant in Brazil. Another risk is the sustainability risk in new plant. However, the concept of sustainability is limited to environmental risk (Company G). Companies D, E, and G separately mentioned health and safety risk within the concept of sustainability risk. Interpretation of this risk is not just limited to health and safety in plant but also to customers (Companies D \& E). Company G referred to productivity and performance risk and company $\mathrm{C}$ identified high levels of inventory as a risk.

Procurement Risk: New plant is exposed to risks from procurement activity. Company B experienced supplier's insolvency risk, which resulted in lower production output. Company B stated that chances of this risk occurring has been reduced as they have taken major steps to ensure that their suppliers are financially sound and it monitors the financial soundness of their suppliers. Companies A, B, C, D \& F have mentioned that some of their components are supplied by single supplier. If something goes wrong with that supplier then production will suffer. Companies are looking for cost effective and IPR protection solution for single source supply risk. Higher bargaining power of suppliers increases the supplier change risk, mentioned by companies A, B, D, and E. 
Companies B, D, E, and G highlighted the risk related to raw materials' quality, availability and cost. Raw material quality is particularly important for companies related to food industry as their products are related to customers' health but companies related to the chemical industry and engineering services companies also express concerned about raw material quality risk. On the other hand, company $\mathrm{C}$, whose core production focus is on assembling, mentioned about time-totime shortage of components as they source components from the Far East. Procurement disruption risk in the Far East or disruption in the logistics increases this risk.

Suppliers' capacity risk arises when companies cannot control customers demand. Company B is a small automotive parts' supplier and its suppliers are even smaller. A sudden surge in car demand leads to shortage of supplier's capacity. Company E makes customized engineering products. It often bids for engineering projects beyond its capacity due to uncertainty in tender process. A favorable outcome of multiple tenders in a year can put its suppliers in capacity stress.

Distribution Risk: New plant is exposed to distribution risks and the terms supply chain disruptions and disruptions are used synonymously used in companies. Companies B, C, D, E, F, and $\mathrm{G}$ mentioned that there are uncertainties in distribution due to external risks. Company $\mathrm{B}$ mentioned that the transportation availability had created short time disruption in distribution. Some industrial customers are demanding automated warehouse facilities. This kind of facility is limited. Demand for technologically advanced warehouse facility not only disrupts the disruption but it also increases cost. Higher distribution cost risk, additionally, increases by the bargaining power of the distributors. Companies $\mathrm{C}$ and $\mathrm{F}$ work with distributors in a transparent way to mitigate this risk. 
Higher distribution cost risk can be exacerbated by shortage of distribution capacity and more importantly by external risks, such as oil price fluctuation. Companies C and F's distribution depends heavily upon dealers. Dealers' loyalty is seen as one of the biggest risks in distribution. Hence, they focus on creating new dealers and on strengthening partnership with existing dealers.

Sales and Marketing Risk: Companies B, D and E highlighted NPI failures risk arising from misunderstanding of local, regional, and global markets. Such misunderstanding leads to new products that do not satisfy the customers' needs relative to other competitive products. NPI profitability risk and product pricing risk arises when price is low and production cost is high, mentioned by companies B, C, D, G, and E. Company E mentioned that their products are customized products and take 6 months to produce. However, the price of the product is determined six months before, which leads to NPI profitability and product pricing risk.

Companies D and $\mathrm{E}$ believe that they have robust processes for customer relationship management. However, customer mismanagement and responsiveness risk is one of the concerns for global manufacturers in the view of companies A, B, C, E and G. The source of this risk lies in the responsiveness of the global manufacturers. Customers are becoming increasingly demanding, especially in the case of industrial customers.

Company B has its own branded products and it also makes branded products for its industrial customers. Its branded products compete with its industrial customers' brand in the same market. 
This kind of competition has created a unique kind of brand performance risk to the sales and marketing division of the Company. Retaining market share risk arises when there is perfect competition in the market (Company G). Corporate image and customer agitation risks appear when company products harm customers. Company E's products faults can be dangerous to the customers commercial infrastructure whereas company D's products' are directly responsible for customers' health. However, publicly available information on corporate image risk illustrates many facets of its origin such as ethics, sustainability etc.

Strategic and Financial Risk: New plant is exposed to strategic and financial risks. Companies C, E, F and G highlighted that strategic alignment as one of the most important factors in the investment decision process. Company $\mathrm{G}$ quoted an investment in production operations in Europe which was being considered for divestment because it was not strategically aligned. Company A mentioned financial institution confidence risk. This risk is not only a hindrance to growth but can impact day to day operations. Credit risk, market risk, investor confidence risk were observed in companies E, F \& G. All these companies are listed in the stock exchange. Company $\mathrm{G}$ mentioned that new investment could push the share price up or down.

External Risk: Field studies revealed that new plant investment is exposed to risks from the external environment. Investigated companies were more forthright in describing external risks than internal risks. Among all the external risks, currency fluctuation risk is highlighted in the confidential investment documents of the companies B, C E, F, and G. Local sourcing and local market is a solution to mitigate this risk as mentioned by company B. External risks can be location specific in nature such as cultural risk, language risk, tax rate risk, local competition 
risk, corruption risk, market access risk, and local politics risk. However, external risks also arise from global business environment such as maturity of customers industry, technology change risk, economic slowdown, global competition and global politics. Corruption risk arises when a company chooses investment location where there is discretion in local governance without any accountability. Corruption increases cost and it also increases the litigation risk. If corruption charges are proved, then there is monetary punishment and it is also linked to corporate image damage risk as stated by company $\mathrm{F}$.

\subsection{Investment Risk Management Dimensions}

The dimensions of risk management in plant investment emerged from a series of explicit and implicit practices in plant investment. These dimensions are part of the broader framework of risk management as shown in the Table 5. The foundation of identifying dimensions is based on risk management mapping of seven global manufactures' investment projects individually. Table 3 shows key explicit and implicit risk management practices and supporting cases. It presents the theoretical logic of nature (explicit and implicit risk management) practices and then links these with the key dimensions of investment risk management. They are as follows:

Risk management objective: Risk management objective is perhaps the most important dimensions providing as it does the focus for the other dimensions Companies derive risk management objectives from new plant investment strategies which in turn are designed to enhance a company's returns or 'rewards'. Since risk is associated with reward, the strategies of investment represent implicit risk management objectives. 
Risk areas: It is observed that many global manufacturers seek specific operational areas where they can improve their performance. Their plant investment processes typically reflect the areas where global manufacturers are actively looking for expected rewards. As expected reward has uncertainty, which means the areas of expected reward generation are the areas where risk comes from. It was observed from practices that these risk areas are factory network, value chain, business and industry, investment project management, country/locations, and risk register (Table $2 \& 3$ )

Quantitative risk assessment: Companies typically performs objective assessment if historical data is available. Key quantitative risk assessment methods were observed. These methods are DCF, CAPM, sensitivity analysis, real options, and exit analysis. DCF analysis explicitly assesses the reward. As reward is associated with risk, it is implicitly assessing the risk as well. In other words, DCF analysis also assesses' potential losses implicitly if the investment fails. It is illustrated in Company G's DCF analysis, where the company uses exit analysis to determine cost of investment failure and to cut the losses in investment. However, quantitative analysis does not include individual risk objectively. It is therefore difficult to identify which individual risk or a set of individual risks have caused the variance in NPV. These implicit and explicit methods of risk assessment constitute the third dimensions of risk management.

Qualitative risk assessment: Subjective assessment is required if historical data is not available. Key implicit and explicit qualitative risk assessment practices have been identified. These factors are SWOT (Strength, Weakness, Opportunity and Threat), country/location, project management, value chain, strategic alignment, investment attractiveness, scenario analysis and 
project portfolio, which vary in individual analysis. Some of these factors' analyses overlap. For example, value chain analysis and operations/ network analysis overlaps with scenario analysis. The qualitative risk assessment is a semi scientific method of risk assessment. Company G had developed a method of selecting investment project to reorganize its factory network. This method is called project portfolio analysis. The problem with this method is that the company' executives are assigning weights to more than 100 factors based on their best guess to determine risk of the investment and the investment attractiveness. It is observed that all the qualitative risk assessment methods are necessarily based on subjective judgment.

Risk decision: This dimension is required once risks are identified in an plant investment project. This research has identified three implicit risk decisions - accept the risk (accept the investment), reject the risk (reject the investment project) and postpone the risk (postponed the investment, which is found exclusively in company G). Investment projects are associated with reward (however reward expressed in NPV terms is associated with identified and unidentified risk) and risk. Hence, the decisions related to investment projects represent the decisions related to investment risks also, which make risk decision the fifth dimensions of the risk management.

Risk mitigation: This dimension deals with strategies to minimize risks. In-depth case studies in global manufacturing companies illustrated various strategies to protect the investment such as training, communication, supply chain protection and implementation of best manufacturing practices. It is observed that these practices developed over time due to historical or recent bad experiences in plant investment. However, these practices do not align with identified risks in the companies and also do not align with qualitatively and quantitatively assessed risks. These 
practices are directly protecting the value of the investment if things go wrong, in other words mitigating investment risks.

Risk indicators: Every company in this research has some kind of investment performance indicator. Examples of indicators include business performance, product performance matrix, process performance matrix and periodic review. These indicators can be divided into three types - project management indicators, financial investment performance indicators and non-financial investment performance indicators. In the absence of systematic investment risk management, these investment project indicators are implicit risk indicators, hence forming another dimension of the risk management in plant investment.

Periodic review: Global manufacturers with the help of risk indicators periodically review their investment projects. Companies $\mathrm{C}, \mathrm{F}$ and $\mathrm{G}$ review the whole purpose of the investment, several times each year. Company $\mathrm{C}$ found four extra benefits of its global plant footprint investment projects during the periodic review - capacity, cost reduction, currency balance and customer responsiveness, which benefits checking of risk implicitly in timely intervals. Periodic review is the last observe dimension of risk management in plant investment.

\subsection{Structure and rationale for proposed Risk Management Process}

There are theoretical and practical limitations to the plant investment risk management perspective in global manufacturing. Case analysis has provided insights by integrating the findings from literature review, field studies and cross case analysis of risk management 
practices. A process development approach is shown in table 7. This proposed process has four connected sub processes - risk identification process, risk assessment process, risk administration process and risk monitoring process, which include following steps.

Risk identification process: The investment risk management process starts with identifying the objective. Risk management objectives provide the nature of risk that a company should investigate in its plant investment. These objectives are not limited to investment objectives that are determined by the investment strategy but include business and manufacturing strategy. Investigated companies provided indirect reference to the risk management objectives providing the basis for the first, second and third steps of risk identification - business strategy, manufacturing strategy and investment strategy. According to these objectives, risks should be aligned with risk areas. Risk identification provides the risk profile for the investment project, which is the fifth step of the process.

'Insert Table 7 here'

'Insert Figure 1 here'

Risk assessment process: This sub process has five steps. The first step is the categorization of the risk profile into the nature of measurability (subjective and objective). The second step involves the assessment of subjective risk based on experience of employees. It requires estimating uncertainty and impact. The third is objective risk assessment, which requires historical data enabling the determination of uncertainty and impact using statistical tools. Integration of all these assessment steps provides a risk map for a plant investment project. The fourth step is to incorporate risk in a DCF calculation to determine the risk-adjusted value of an investment project. 
Risk administration process: This sub process has three steps. The first step is to determine if risk adjusted plant investment project is financially viable or not. If it is not desirable then the company has to take a decision on the rejection or postponement of the investment project. If risk adjusted value is acceptable, then risk mitigation strategies are needed to minimize risk. This step involves risk decision and risk mitigation.

Risk monitoring process: This sub process has two steps. The first step is to determine risk indicators for the investment project and the second step requires monitoring these risk indicators regularly. Risk monitoring requires periodic review process. The periodic review process repeats the sub processes of investment risk management.

The application of above proposed processes framework requires creativity and scientific knowledge. While this process is not fully tested, the approach is overarching in wide range of global manufacturing companies. It can be argued that any application of the framework approach must be sensitive to practical behavioral issues such as trust, relationship, knowledge, and hierarchy. Such consideration cannot be incorporated in the framework itself but sensible incorporation in user guide will facilitate allowance of behavioral issues, where appropriate.

\section{Conclusion}

This paper explores risk management practices in plant investment. It reflects the growing internationalization of manufacturing and the increasing complexity and fragmentation of manufacturing systems. Issues of risk management have become increasingly important in 
financial and company governance contexts not least because of growing international concerns about the consequences of unregulated risk. However while significant progress has been made in the awareness and articulation of financial risk there appeared to be little evidence of systematic management of risks associated with the globalization of manufacturing despite the fact that ill-advised internationalization projects could risk companies' futures. Investment risk management practice has evolved as risk analysis in plant investment from theoretical and practice perspectives. The need to actively manage risk has tended to be lost by the adoption of complex financial risk analysis methods in industrial investment projects that calls for an industrial risk management.

Plant Investment risk management theory states that risks emerge from external environment, organization and value activities. Management of these risks requires objective, risk areas, qualitative and quantitative assessment, risk decision, mitigation, risk indicators and periodic review. All these processes are part of the border framework risk management theory.

The key findings are as follows:

- Elements of new plant investment risk are managed by a variety of implicit and explicit methods, typically embedded in strategic and financial evaluations. There are no widely recognized comprehensive and systematic approaches to the analysis and mitigation of risks associated with plant investments.

- A broad review and analysis of plant investment projects identified key categories of investment risks and key dimensions of investment risk management. 
- A framework for plant risk management process architecture is proposed based upon the key research findings. It presents a structured approach to the key risk management tasks and demonstrates their generality across a range of industrial environment. This provides confidence though not conclusive evidence that these methods might be applicable across a broad spectrum of manufacturing industries.

The empirical findings are an extension of risk management theories into the manufacturing domain. Research findings have partial resemblance with risk management structure theories and theoretical risk categorization because this research is the first exploratory study of risk management in plant investment. The multidisciplinary approach provides the theoretical triangulation of the research.

The classification of plant investment risks can help companies and practitioners to identify risk because it indicates the sources of risks rather than claiming to identify 'the' risk. Application of the proposed risk management process framework might provide better understanding of plant investment decision and capability to manage risk. Additionally, key findings may help risk auditors and practitioners in the establishment of corporate risk management, where risk management system will not only satisfy the regulatory requirement but it will also develop risk related capabilities. The research findings extend the current understanding of risk management into the domain of global manufacturing strategy and provide the basis for more comprehensive and systematic assessment of risk in plant investment projects. Further research will be required to validate the proposed risk management process and to explore the particular risks associated with different sectors, technologies, and business contexts. 


\section{Reference}

Burgess, R. G. 1984. In the field: An introduction to field research. New York, NY: Routledge. Cook, T. D., \& Campbell, D. T. 1979. Quasi-experimentation: design and analysis issues for field settings. Chicago, IL, USA: Rand McNally.

Crouhy, M., Galai, D., \& Mark, R. 2006. The Essentials of Risk Management. New York, USA: McGraw-Hill.

Dabhilkar, M., \& Bengtsson, L. 2008. Invest or divest? On the relative improvement potential in outsourcing manufacturing. Production Planning and Control, 19(3): 212-228.

Dhankar, R. S., \& Singh, R. 2005. Arbitrage pricing theory and the capital asset pricing model: evidence from the Indian stock market. Journal of Financial Management and Analysis, 18(1): 14-27.

Dixit, A. 1992. Investment and hysteresis. The journal of economic perspectives, 6(1): 107-132.

DuBois, F. L., Toyne, B., \& Oliff, M. D. 1993. International manufacturing strategies of US multinationals: a conceptual framework based on a four-industry study. Journal of International Business Studies: 307-333.

Eversheim, W. 1997. Manufacturing excellence in global markets. London, UK: Chapman \& Hall.

Feldmann, A., Olhager, J., \& Persson, F. 2009. Designing and managing manufacturing networks-a survey of Swedish plants. Production Planning and Control, 20(2): 101112.

Hagstrom, R. G. 1997. The Warren Buffett way: Investment strategies of the world's greatest investor. New York, NY, USA: John Wiley \& Sons.

Harrington, S. E., Niehaus, G. R., \& Harrington, N. 2003. Risk management and insurance: McGraw-Hill.

Hayes, R. H., \& Wheelwright, S. C. 1984. Restoring Our Competitive Edge: Competing Through Manufacturing. New York, NY, USA: John Wiley \& Sons.

Head, G. L., \& Horn I I, S. 1991. Essentials of risk management. Malvern, PA, USA: Insurance Institute of America.

Henzler, H., \& Rall, W. 1986. Facing up to the globalization challenge. McKinsey Quarterly, Winter86(1): 52-68.

Hertz, D. B. 1979. Risk analysis in capital investment. Harvard Business Review, 57(5): 169181.

Jagric, T., Podobnik, B., \& Kolanovic, M. 2005. Does the Efficient Market Hypothesis Hold?: Evidence from Six Transition Economies. Eastern European Economics, 43(4): 79-103.

Kallman, J. W., \& Maric, R. V. 2004. A Refined Risk Management Paradigm. Risk Management, 6(3): 57-68.

Kazlauskiene, V., \& Christaukas, C. 2007. Risk Reflection in Business Valuation Methodology. Economics of Engineering Decisions, 51(1): 7-15.

Kumar, M., \& Gregory, M. 2007. Global manufacturing network transformation management: risk and reward perspective, 1st European Risk Conference. Münster, Germany: 1st European Risk Conference.

Kumar, M., \& Gregory, M. 2011. Risk Management in Global Manufacturing Investment: Dimensions and Process, 18th International Annual European Operations Management Association Conference. Cambridge, UK. 
Kumar, M., \& Gregory, M. 2013. An exploration of risk management in global industrial investment. Risk management, 15(4): 272-300.

Leonard-Barton, D. 1990. A dual methodology for case studies: synergistic use of a longitudinal single site with replicated multiple sites. Organization Science, 1(3): 248-266.

Macgill, S. M., \& Siu, L. Y. 2005. A New Paradigm for Risk Analysis. Futures, 37: 1105-1131.

Magni, C. A. 2002. Investment decisions in the theory of finance: Some antinomies and inconsistencies. European Journal of Operational Research, 137(1): 206-217.

Meredith, J. 1998. Building operations management theory through case and field research. Journal of Operations Management, 16(4): 441-454.

Merna, T., \& Al-Thani, F. F. 2005. Corporate Risk Management: an oganisational Perspective. West Sussex, England: John Wiley \& Sons, Ltd.

Morrison, A., \& Roth, K. 1993. Relating Porter's Configuration/Coordination Framework to Competitive Strategy and Structural Mechanisms: Analysis and Implications. Journal of Management, 19(4): 797.

Mullins Jr, D. W. 1982. Does the capital asset pricing model work? Harvard Business Review, 60(1): 105-113.

Parry, T. G. 1975. The product cycle and international production: UK pharmaceuticals. The Journal of Industrial Economics, 24(1): 21-28.

Porter, M. E. 1986. The strategic role of international marketing. Journal of Consumer Marketing, 3(2): 17-21.

Pratt, J. W., \& Hammond II, J. S. 1979. Evaluating and comparing projects: simple detection of false alarms. The Journal of Finance, 34(5): 1231-1242.

Roth, A. V., \& Miller, J. G. 1992. Success Factors in Manufacturing. Business Hoizons, 35(4): 73-82.

Shi, Y., \& Gregory, M. 1998. International manufacturing networks - to develop global competitive capabilities. Journal of Operations Management, 16(2/3): 195-214.

Skinner, W. 1969. Manufacturing--missing link in corporate strategy. Harvard Business Review, 47(3): 136-145.

Srai, J. S., Bertoncelj, A., Fleet, D., \& Gregory, M. 2010. An operations process framework for international M\&A value creation. European Journal of International Management, 4(1): 3-29.

Trigeorgis, L. 2005. Making use of real options simple: an overview and applications in flexible/modular decision making. The Engineering Economist, 50(1): 25-53.

Vernon, R. 1966. International Investment and International Trade in the Product Cycle. Quarterly Journal of Economics, 80(2): 190-207.

Voss, C., Tsikriktsis, N., \& Frohlich, M. 2002. Case research in operations management. International Journal of Operations \& Production Management, 22(2): 195-219.

Wheelwright, S. C. 1978. Reflecting Corporate Strategy in Manufacturing Decisions. Business Horizons, 21(1): 57-67.

Yin, R. K. 1994. Case study research : Design and Methods. Beverly Hills, CA, USA: Sage Publications. 
Table 1: With-in-Case Analysis- Strategic, Manufacturing and Plant Investment objectives

\begin{tabular}{|c|c|c|c|c|}
\hline & $\begin{array}{l}\text { Business } \\
\text { Review }\end{array}$ & $\begin{array}{l}\text { Strategic } \\
\text { Objectives }\end{array}$ & $\begin{array}{l}\text { Manufacturing } \\
\text { Objectives }\end{array}$ & $\begin{array}{l}\text { Plant Investment } \\
\text { Objectives }\end{array}$ \\
\hline 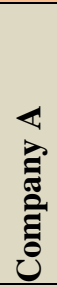 & $\begin{array}{l}\text { CNC precision engineering } \\
\text { company. } \\
\text { Automotive contract } \\
\text { manufacturer } \\
\text { Annual revenue is } \$ 4 \\
\text { million } \\
\text { Privately owned company } \\
\end{array}$ & $\begin{array}{l}\text { Double its revenue } \\
\text { Low cost of operations } \\
\text { Differentiations from } \\
\text { peers } \\
\text { Right skill sets }\end{array}$ & $\begin{array}{l}\text { Higher quality } \\
\text { Lower cost } \\
\text { Maintaining } \\
\text { working capital } \\
\text { Production on time }\end{array}$ & $\begin{array}{l}\text { Minimisation of cost } \\
\text { Ahead in competition }\end{array}$ \\
\hline है & $\begin{array}{l}\text { Global producer and } \\
\text { distributor of household } \\
\text { products } \\
\text { Privately owned company } \\
\text { with annual revenue of } \$ 180 \\
\text { million } \\
\text { Market segments-contract } \\
\text { manufacturing and } \\
\text { production of own branded } \\
\text { products }\end{array}$ & $\begin{array}{l}\text { Increase its turnover } \\
\text { Operations expansion } \\
\text { Brand performance } \\
\text { Brand development } \\
\text { Operating margin } \\
\text { Customer relation } \\
\text { NPI }\end{array}$ & $\begin{array}{l}\text { Reduce cost } \\
\text { Align production } \\
\text { with sales } \\
\text { Capacity balance } \\
\text { Customer } \\
\text { responsiveness } \\
\text { Unique products }\end{array}$ & $\begin{array}{l}\text { Alignment of } \\
\text { production with sales } \\
\text { Low cost location } \\
\text { within the proximity of } \\
\text { market } \\
\text { Increase in market } \\
\text { share } \\
\text { Customer } \\
\text { responsiveness }\end{array}$ \\
\hline 己े & $\begin{array}{l}\text { A non-stock exchange listed } \\
\text { subsidiary of a fortune } 500 \\
\text { companies, } \\
\text { Annual revenue of } \$ 500 \\
\text { million } \\
\text { Produces diesel and gas } \\
\text { generator sets globally at } \\
\text { five locations }\end{array}$ & $\begin{array}{l}\text { Market expansion } \\
\text { Production expansion } \\
\text { Cost effective key parts } \\
\text { sourcing } \\
\text { Inventory reduction } \\
\text { Supply chain risk } \\
\text { management }\end{array}$ & $\begin{array}{l}\text { Capacity balance } \\
\text { Lower cost } \\
\text { Increase capacity } \\
\text { Production near to } \\
\text { market }\end{array}$ & $\begin{array}{l}\text { Currency balance } \\
\text { Capacity balance } \\
\text { Increase capacity } \\
\text { Supply management } \\
\text { Reduce lead time } \\
\text { Increase market share }\end{array}$ \\
\hline 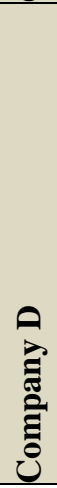 & $\begin{array}{l}\text { Global food product } \\
\text { manufacturer } \\
\text { Annual revenue of } \\
\text { approximately } \$ 22 \text { billion } \\
\text { Privately owned company } \\
\text { and has presence in } 66 \\
\text { countries. }\end{array}$ & $\begin{array}{l}\text { Product Quality, Brand } \\
\text { improvement, } \\
\text { Consumer } \\
\text { responsiveness, Low } \\
\text { price } \\
\text { Accountability, People } \\
\text { Sustainability, } \\
\text { Suppliers relationship } \\
\text { Waste \& Cost reduction } \\
\text { Market share growth } \\
\text { (or growth in revenue) } \\
\text { and profit maximisation }\end{array}$ & $\begin{array}{l}\text { Production } \\
\text { proximity to } \\
\text { customers } \\
\text { Cost reduction }\end{array}$ & $\begin{array}{l}\text { Market expansion } \\
\text { Profit maximisation } \\
\text { Protection of the } \\
\text { Company D's global } \\
\text { operation }\end{array}$ \\
\hline
\end{tabular}


Table 2: With-in-Case Analysis - Strategic, Manufacturing and Plant Investment objectives

\begin{tabular}{|c|c|c|c|c|}
\hline & $\begin{array}{c}\text { Business } \\
\text { Review }\end{array}$ & $\begin{array}{c}\text { Strategic } \\
\text { Objectives }\end{array}$ & $\begin{array}{c}\text { Manufacturing } \\
\text { Objectives }\end{array}$ & $\begin{array}{c}\text { Plant Investment } \\
\text { Objectives }\end{array}$ \\
\hline 己َ & $\begin{array}{l}\text { - Global engineering } \\
\text { company } \\
\text { - European public company } \\
\text { with annual revenue of } \\
\text { approximately } \$ 30 \text { billion. } \\
\text { - Five business divisions }\end{array}$ & $\begin{array}{l}\text { - Business execution } \\
\text { - Cost reduction } \\
\text { - Risk management - } \\
\text { supply and currency } \\
\text { - Organic growth }\end{array}$ & $\begin{array}{l}\text { - Globally } \\
\text { integrated } \\
\text { operation } \\
\text { - Cost reduction } \\
\text { - Globally } \\
\text { balanced } \\
\text { capacity- } \\
\text { proximity to } \\
\text { customers } \\
\end{array}$ & $\begin{array}{l}\text { - Develop new } \\
\text { market } \\
\text { - Capacity balance } \\
\text { - Risk management- } \\
\text { supply chain }\end{array}$ \\
\hline 己 & $\begin{array}{l}\text { - Global manufacturer of } \\
\text { diesel engine, turbine, } \\
\text { construction machinery, } \\
\text { and earth moving } \\
\text { machines } \\
\text { - Stock exchange listed } \\
\text { company with annual } \\
\text { revenue of } \$ 30 \text { billion } \\
\text { - Target markets natural } \\
\text { resource extraction, } \\
\text { infrastructure } \\
\text { construction, power } \\
\text { generation }\end{array}$ & $\begin{array}{l}\text { - Leadership, } \\
\text { engagement, health and } \\
\text { safety, training for } \\
\text { managers } \\
\text { - NPI, order to delivery, } \\
\text { Brand management } \\
\text { - Warranty, suppliers } \\
\text { defects } \\
\text { - Speed of production } \\
\text { - Effective distribution } \\
\text { channel } \\
\text { - Market expansion, } \\
\text { additional capacity, } \\
\text { cost reduction } \\
\text { - Planning for cyclical } \\
\text { downturn }\end{array}$ & $\begin{array}{l}\text { - Common } \\
\text { processes } \\
\text { - World class } \\
\text { quality } \\
\text { - Cost reduction } \\
\text { - Capacity } \\
\text { balance- } \\
\text { assembly plant } \\
\text { vs. component } \\
\text { plants }\end{array}$ & $\begin{array}{l}\text { - Price competitive } \\
\text { locations } \\
\text { - Proximity to } \\
\text { customer: expansion } \\
\text { in emerging markets } \\
\text { - Right ratio of } \\
\text { assembly and } \\
\text { component plants }\end{array}$ \\
\hline 己̇ं & $\begin{array}{l}\text { - Global manufacturer of } \\
\text { protective packaging } \\
\text { material and systems } \\
\text { - Stock exchange listed } \\
\text { company with annual } \\
\text { revenue of } \$ 4.6 \text { billion }\end{array}$ & $\begin{array}{l}\text { - Becoming fortune } 100 \\
\text { companies. } \\
\text { - Customer relationship } \\
\text { - Increasing shareholders } \\
\text { value } \\
\text { - Increase market share } \\
\text { in new markets } \\
\text { - Operational growth in } \\
\text { emerging market }\end{array}$ & $\begin{array}{l}\text { - Operational cost } \\
\text { reduction } \\
\text { - Productivity } \\
\text { improvement } \\
\text { - Expansion in } \\
\text { emerging market }\end{array}$ & $\begin{array}{l}\text { - Cost reduction } \\
\text { - Geographical } \\
\text { capacity balance } \\
\text { - Increasing turnover } \\
\text { - Productivity } \\
\text { improvement } \\
\text { - Emerging markets }\end{array}$ \\
\hline
\end{tabular}


Table 3: With-in-Case Analysis- Risk management

\begin{tabular}{|c|c|c|c|c|c|}
\hline & \multirow[t]{2}{*}{ Risks } & \multicolumn{4}{|c|}{ Explicit and Implicit Plant Investment Risk Management } \\
\hline & & Identification & Assessment & Administration & Monitoring \\
\hline 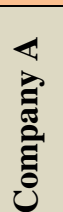 & $\begin{array}{l}\text { - Risk is threat } \\
\text { - No documentation } \\
\text { - Intuitive risk understanding }\end{array}$ & $\begin{array}{l}\text { - Business screening } \\
\text { - Investment project } \\
\text { screening } \\
\text { - Intuitive risk }\end{array}$ & $\begin{array}{l}\text { - Discount Cash Flow } \\
\text { - Country Risk- CAPM }\end{array}$ & $\begin{array}{l}\text { - Accepting Investment risks } \\
\text { - Rejecting investment risk } \\
\text { - Risk mitigation: cost control }\end{array}$ & - Cost monitor \\
\hline 离 & $\begin{array}{l}\text { - Risk is threat } \\
\text { - No documentation } \\
\text { - Intuitive risk understanding } \\
\text { - Political risk and chemical } \\
\text { industry risks } \\
\text { - Operational risk equivalent } \\
\text { to investment risk } \\
\end{array}$ & $\begin{array}{l}\text { - Operational } \\
\text { understanding } \\
\text { - Industry knowledge } \\
\text { - Currency and IPR } \\
\text { risk are explicitly } \\
\text { identified } \\
\text { - SWOT Analysis }\end{array}$ & $\begin{array}{l}\text { - DCF } \\
\text { - CAPM } \\
\text { - Sensitivity analysis } \\
\text { - Qualitative risk evaluation }\end{array}$ & $\begin{array}{l}\text { - Accepting Investment risks } \\
\text { - Rejecting investment risk } \\
\text { - Risk mitigation: cost control, } \\
\text { coordination, knowledge transfer, } \\
\text { supporting project, multiple suppliers }\end{array}$ & $\begin{array}{l}\text { - Cost } \\
\text { - Gross Margin, } \\
\text { - Inventory } \\
\text { - Speed in supply } \\
\text { chain } \\
\text { - Customer } \\
\text { responsiveness }\end{array}$ \\
\hline 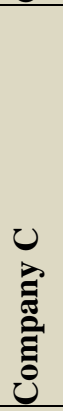 & $\begin{array}{l}\text { - Risk is threat } \\
\text { - No documentation } \\
\text { - Levels of risk: corporate, } \\
\text { operational and investment } \\
\text { project } \\
\text { - Explicit currency risk } \\
\text { - Explicit risk management } \\
\text { process }\end{array}$ & $\begin{array}{l}\text { - Parent company's } \\
\text { risk register } \\
\text { - Business strategy } \\
\text { - Manufacturing vision } \\
\text { - Value chain } \\
\text { screening } \\
\text { - Project management } \\
\text { risk identification } \\
\text { - Intuitive risk } \\
\text { - SWOT Analysis } \\
\end{array}$ & $\begin{array}{l}\text { - Qualitative evaluation-value } \\
\text { chain } \\
\text { - DCF/CAPM } \\
\text { - Sensitivity analysis } \\
\text { - Alignment of investment } \\
\text { - Explicit Qualitative risk- } \\
\text { project management } \\
\text { - Intuitive risk evaluation }\end{array}$ & $\begin{array}{l}\text { - Accepting Investment risks } \\
\text { - Rejecting investment risk } \\
\text { - Risk mitigation: best practices, } \\
\text { ownership \& accountability, local } \\
\text { supply base, training, coordination } \\
\text { mechanism }\end{array}$ & $\begin{array}{l}\text { - Cash flow } \\
\text { - Global footprint } \\
\text { indicators } \\
\text { - Project } \\
\text { management } \\
\text { indicators }\end{array}$ \\
\hline 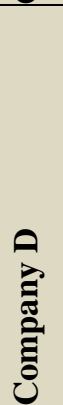 & $\begin{array}{l}\text { - Risk is threat } \\
\text { - No documentation at } \\
\text { company level } \\
\text { - Corporate level risk and } \\
\text { operational level risk has } \\
\text { direct or indirect impact on } \\
\text { investment project } \\
\text { - External risk increases the } \\
\text { intensity of internal risks }\end{array}$ & $\begin{array}{l}\text { - KSF of business } \\
\text { strategy } \\
\text { - Manufacturing vision } \\
\text { - Investment objectives } \\
\text { - Factory network }\end{array}$ & $\begin{array}{l}\text { - Qualitative evaluation: role } \\
\text { of factory, site location, plant } \\
\text { design, network optimisation } \\
\text { - DCF } \\
\text { - CAPM } \\
\text { - Real Option }\end{array}$ & $\begin{array}{l}\text { - Accepting Investment risks } \\
\text { - Rejecting investment risk } \\
\text { - Risk mitigation: start small operation, } \\
\text { co-manufacturing, micro plant/ } \\
\text { temporary facility, partial conversion, } \\
\text { supply protection, product } \\
\text { compliance, right product, flexibility } \\
\text { for expansion, best practices for } \\
\text { performance }\end{array}$ & $\begin{array}{l}\text { - Capacity gap } \\
\text { - New market } \\
\text { development } \\
\text { - Profitability }\end{array}$ \\
\hline
\end{tabular}




\begin{tabular}{|c|c|c|c|c|c|}
\hline & \multirow{2}{*}{ Risks } & \multicolumn{4}{|c|}{ Explicit and Implicit Plant Investment Risk Management } \\
\hline & & Risk Identification & Risk Assessment & Risk Administration & Risk Monitoring \\
\hline 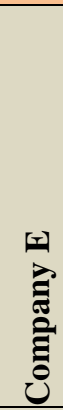 & $\begin{array}{l}\text { - Risk is threat } \\
\text { - ERM implementation } \\
\text { - Key risk factors are published } \\
\text { in 10K report } \\
\text { - Risk categories in investment: } \\
\text { political, economic, societal } \\
\text { and technological }\end{array}$ & $\begin{array}{l}\text { - Explicit country risk identification } \\
\text { and Manufacturing and engineering } \\
\text { network review } \\
\text { - Implicit location risk and operational } \\
\text { risk identification but strategic level } \\
\text { not related to specific investment } \\
\text { project } \\
\text { - Global footprint objectives } \\
\text { - Risk register / preconceive } \\
\text { understanding of risk (Intuitive) }\end{array}$ & $\begin{array}{l}\text { - Qualitative evaluation- } \\
\text { country risk, } \\
\text { manufacturing and } \\
\text { network review, } \\
\text { strategic alignment, } \\
\text { operational scenario, } \\
\text { site scenario } \\
\text {-DCF } \\
\text { - CAPM }\end{array}$ & $\begin{array}{l}\text { - Risk avoidance } \\
\text { - Risk mitigation } \\
\text { - Risk mitigation strategies: operations } \\
\text { excellence, supply management, } \\
\text { strategic alignment, improvement of } \\
\text { business performance through product } \\
\text { and process attribute, flexibility, use } \\
\text { of single currency }\end{array}$ & $\begin{array}{l}\text { - Business } \\
\text { performance } \\
\text { - Product } \\
\text { performance matrix } \\
\text { - Process } \\
\text { performance matrix } \\
\text { - Project management } \\
\text { indicators } \\
\text { - Periodic review }\end{array}$ \\
\hline 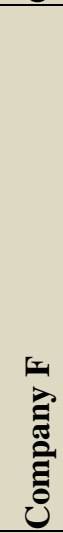 & $\begin{array}{l}\text { - Risk is threat } \\
\text { - ERM implementation } \\
\text { - Key risk factors are published } \\
\text { in 10K report } \\
\text { - Difference between published } \\
\text { risk, risk identified through } \\
\text { interview and risks in } \\
\text { confidential document } \\
\text { developed with consulting firm } \\
\text { - Risk categories: Strategic, } \\
\text { operational, external, financial } \\
\text { and people }\end{array}$ & $\begin{array}{l}\text { - Implicit: Plant network analysis } \\
\text { - Implicit Investment screening } \\
\text { - Implicit investment decision factors } \\
\text { - Strategic alignment } \\
\text { - Risk register/ preconceive } \\
\text { understanding of risk (Intuitive) } \\
\text { - SWOT analysis }\end{array}$ & $\begin{array}{l}\text { - Qualitative evaluation- } \\
\text { plant, investment and } \\
\text { decision factors, } \\
\text { strategic alignment, } \\
\text { capabilities, cost } \\
\text { effectiveness } \\
\text { - DCF } \\
\text { - CAPM } \\
\text { - Scenario Analysis } \\
\text { - Risk assessment based } \\
\text { on country, business } \\
\text { environment and hurdle } \\
\text { rate }\end{array}$ & $\begin{array}{l}\text { - Risk avoidance } \\
\text { - Risk mitigation } \\
\text { - Risk Mitigation strategies: training, } \\
\text { communication, supply chain } \\
\text { protection, implementation of best } \\
\text { manufacturing practices }\end{array}$ & $\begin{array}{l}\text { - Capacity } \\
\text { contribution } \\
\text { - New market } \\
\text { development } \\
\text { - Profitability } \\
\text { - Project management } \\
\text { indicators } \\
\text { - Period review of } \\
\text { above factors }\end{array}$ \\
\hline 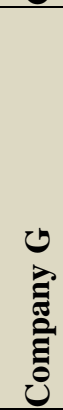 & $\begin{array}{l}\text { - Risk is threat } \\
\text { - ERM implementation } \\
\text { - Key risk factors are published } \\
\text { in 10K report } \\
\text { - Difference between published } \\
\text { risk and risk identified through } \\
\text { interview }\end{array}$ & $\begin{array}{l}\text { - Capability analysis } \\
\text { - Implicit Global plant network risk } \\
\text { analysis } \\
\text { - Investment screening factors } \\
\text { - Strategic alignment } \\
\text { - Risk register/preconceive } \\
\text { understanding of risk (Intuitive) } \\
\text { - Scenario evaluation } \\
\text { - SWOT analysis }\end{array}$ & $\begin{array}{l}\text { - Qualitative assessment: } \\
\text { Plant network } \\
\text { - DCF Analysis } \\
\text { - CAPM } \\
\text { - Exit analysis } \\
\text { - Scenario evaluation } \\
\text { - Portfolio analysis - } \\
\text { Intuition based explicit } \\
\text { risk and attractiveness } \\
\text { analysis }\end{array}$ & $\begin{array}{l}\text { - Risk avoidance (postponement of } \\
\text { investment) } \\
\text { - Explicit Risk Mitigation: currency } \\
\text { exposure, IPR leakage and supply } \\
\text { interruption } \\
\text { - Risk mitigation strategies: start small } \\
\text { (Option), Cross cultural training, } \\
\text { higher automation with use of } \\
\text { technology to protect IPR, Competing } \\
\text { through network, Disrupt market etc. }\end{array}$ & $\begin{array}{l}\text { - Strategic alignment } \\
\text { - Profit performance } \\
\text { - Market performance } \\
\text { - Product } \\
\text { competitiveness } \\
\text { - Project gap analysis }\end{array}$ \\
\hline
\end{tabular}

Table 4: Table 4: With-in-Case Analysis- Risk management 
Table 5: Cross Case Analysis: Plant Investment Risk Management Practices

\begin{tabular}{|c|c|c|c|c|c|c|c|c|}
\hline \multirow{2}{*}{\multicolumn{2}{|c|}{$\begin{array}{c}\text { Identified Practices of Risk Management in Global Manufacturing } \\
\text { Investment }\end{array}$}} & \multicolumn{7}{|c|}{ Case Study } \\
\hline & & $\mathbf{A}$ & $\mathbf{B}$ & $\mathbf{C}$ & $\mathbf{D}$ & $\mathbf{E}$ & $\mathbf{F}$ & $\mathbf{G}$ \\
\hline \multirow{16}{*}{ 氖 } & Implicit risk identification-Business Screening & & & & & & & \\
\hline & Implicit risk identification-Investment project screening & & & & & & & \\
\hline & Implicit risk identification-Intuitive & & & & & & & \\
\hline & Implicit risk identification-Operational understanding & & & & & & & \\
\hline & Implicit risk identification-Industry knowledge & & & & & & & \\
\hline & Explicitly identified risks in investment & & & & & & & \\
\hline & Implicit risk identification-Risk register & & & & & & & \\
\hline & Implicit risk identification-SWOT analysis & & & & & & & \\
\hline & Implicit risk identification- Factory network analysis & & & & & & & \\
\hline & Implicit risk identification-Value chain analysis & & & & & & & \\
\hline & Implicit risk identification-Business strategy & & & & & & & \\
\hline & Implicit risk identification-manufacturing strategy/vision & & & & & & & \\
\hline & Implicit risk identification-project management & & & & & & & \\
\hline & Implicit risk identification-investment objectives & & & & & & & \\
\hline & Explicit risk identification-Country risk & & & & & & & \\
\hline & $\begin{array}{l}\text { Implicit risk identification-Scenario analysis (operational and } \\
\text { location specific) }\end{array}$ & & & & & & & \\
\hline \multirow{13}{*}{ 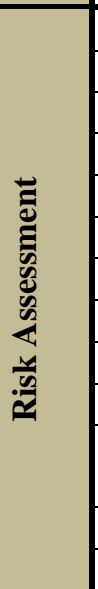 } & Implicit quantitative risk assessment- DCF & & & & & & & \\
\hline & Explicit quantitative risk assessment-CAPM & & & & & & & \\
\hline & Explicit quantitative risk assessment-sensitivity analysis & & & & & & & \\
\hline & Explicit qualitative risk assessment-project management & & & & & & & \\
\hline & Implicit qualitative risk assessment-Investment attractiveness factors & & & & & & & \\
\hline & Implicit qualitative risk assessment- value chain & & & & & & & \\
\hline & Implicit qualitative risk assessment- Strategic alignment & & & & & & & \\
\hline & Implicit risk assessment- Intuitive & & & & & & & \\
\hline & Explicit quantitative risk assessment-Real Option & & & & & & & \\
\hline & Explicit qualitative risk assessment- country risk & & & & & & & \\
\hline & $\begin{array}{l}\text { Implicit qualitative risk assessment- scenario evaluation (operational } \\
\text { \& location specific) }\end{array}$ & & & & & & & \\
\hline & Explicit qualitative risk assessment- portfolio & & & & & & & \\
\hline & Explicit quantitative risk assessment- exist analysis & & & & & & & \\
\hline \multirow{6}{*}{ 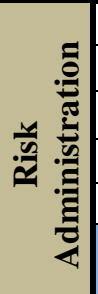 } & Implicit risk administration- accept risk & & & & & & & \\
\hline & Implicit risk administration- reject risk & & & & & & & \\
\hline & Implicit risk administration- postponed risk & & & & & & & \\
\hline & Explicit risk administration-risk mitigation strategies & & & & & & & \\
\hline & Implicit risk administration- risk mitigation strategies & & & & & & & \\
\hline & & & & & & & & \\
\hline \multirow{3}{*}{ 言 } & Implicit risk monitor- project risk & & & & & & & \\
\hline & Implicit risk monitor- various risk indicators & & & & & & & \\
\hline & & & & & & & & \\
\hline
\end{tabular}


Table 6: Cross Case Analysis - Plant Investment Risks

\begin{tabular}{|c|c|c|c|c|c|c|c|c|c|}
\hline \multirow{2}{*}{\multicolumn{2}{|c|}{ Global Manufacturing Investment Risk }} & \multicolumn{7}{|c|}{ Companies } & \multirow{3}{*}{$\begin{array}{c}\text { Repetition } \\
1\end{array}$} \\
\hline & & \multirow{2}{*}{ A } & \multirow{2}{*}{ B } & \multirow{2}{*}{$\mathbf{C}$} & \multirow{2}{*}{ D } & \multirow{2}{*}{$\mathbf{E}$} & \multirow{2}{*}{$\mathbf{F}$} & \multirow{2}{*}{$\mathbf{G}$} & \\
\hline 1 & Risk of brand underperformance & & & & & & & & \\
\hline 2 & Risk of capacity imbalance & & & & & & & & 3 \\
\hline 3 & Risk of changes in labour cost & & & & & & & & 4 \\
\hline 4 & Risk of standard plant design and platform & & & & & & & & 1 \\
\hline 5 & Risk of corporate image damage & & & & & & & & 2 \\
\hline 6 & Risk of exposure to corruption & & & & & & & & 2 \\
\hline 7 & Credit risk & & & & & & & & 3 \\
\hline 8 & Culture barrier risk & & & & & & & & 2 \\
\hline 9 & Currency fluctuation risk & & & & & & & & 5 \\
\hline 10 & Risk of customer agitation & & & & & & & & 1 \\
\hline 11 & Customer mismanagement risk & & & & & & & & 5 \\
\hline 12 & Risk to dealers loyalty & & & & & & & & 1 \\
\hline 13 & Demand fluctuation risk & & & & & & & & 6 \\
\hline 14 & Higher distribution cost and disruption risk & & & & & & & & 5 \\
\hline 15 & Risk of higher distributors bargaining power & & & & & & & & 1 \\
\hline 16 & Economic slowdown risk & & & & & & & & 4 \\
\hline 17 & Employment regulation risk & & & & & & & & 1 \\
\hline 18 & Environment regulation Risk & & & & & & & & 6 \\
\hline 19 & Erroneous valuation risk & & & & & & & & 7 \\
\hline 20 & Risk of lower financial institution's confidence & & & & & & & & 1 \\
\hline 21 & Risk of financial fraud & & & & & & & & 1 \\
\hline 22 & Health and safety risk & & & & & & & & 3 \\
\hline 23 & High level of inventory risk & & & & & & & & 1 \\
\hline 24 & Higher lead time risk & & & & & & & & 1 \\
\hline 25 & Higher new product introduction time risk & & & & & & & & 1 \\
\hline 26 & Higher product transfer time risk & & & & & & & & 1 \\
\hline 27 & Industry decline risk & & & & & & & & 6 \\
\hline 28 & Higher interest rate risk & & & & & & & & 3 \\
\hline 29 & Risk of delay in investment project & & & & & & & & 6 \\
\hline 30 & Lower investor confidence risk & & & & & & & & 2 \\
\hline 31 & IPR leakage risk & & & & & & & & 4 \\
\hline 32 & Language barrier risk & & & & & & & & 1 \\
\hline 33 & Legal barrier risk & & & & & & & & 3 \\
\hline 34 & Local and global competition risk & & & & & & & & 5 \\
\hline 35 & Local and global political instability risk & & & & & & & & 7 \\
\hline 36 & Low quality of product risk & & & & & & & & 2 \\
\hline 37 & Risk of restriction in accessing market & & & & & & & & 1 \\
\hline 38 & Market risk & & & & & & & & 3 \\
\hline 39 & Risk of maturing customers industry & & & & & & & & 1 \\
\hline 40 & New product failure risk from market perspective & & & & & & & & 3 \\
\hline
\end{tabular}




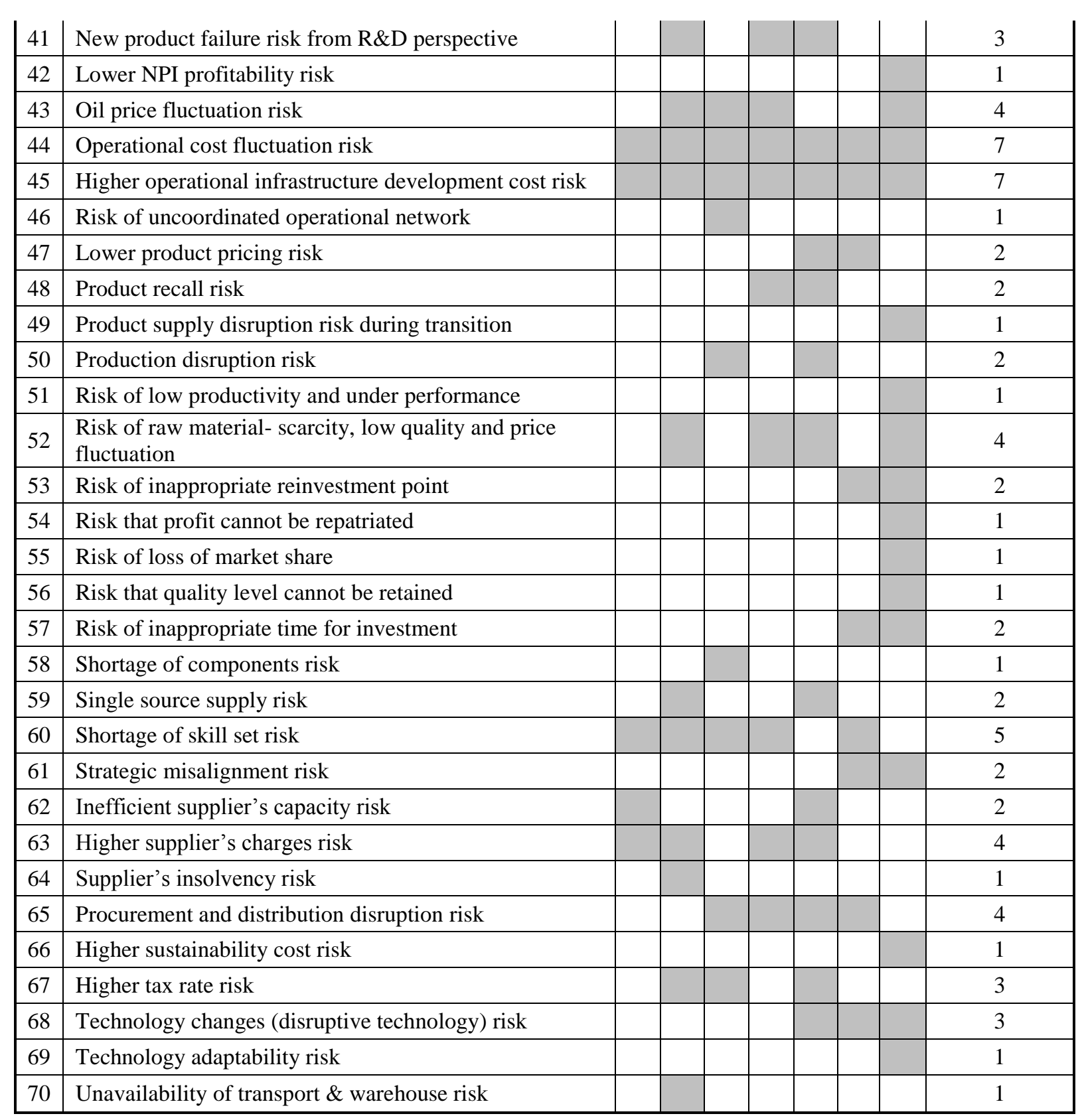


Table 7: Plant Investment risk management process, derived from case data, cross case analysis and existing literature

\begin{tabular}{|c|c|c|c|c|c|}
\hline \multirow{2}{*}{$\begin{array}{l}\text { Primary Risk } \\
\text { Management } \\
\text { Steps }\end{array}$} & \multirow{2}{*}{$\begin{array}{l}\text { Secondary } \\
\text { Processes }\end{array}$} & \multirow{2}{*}{ Key Tasks } & \multirow{2}{*}{ Factors of Secondary Processes } & \multicolumn{2}{|r|}{ Process Gap Informed by } \\
\hline & & & & Case study & Literature \\
\hline \multirow{12}{*}{$\begin{array}{l}\text { Risk } \\
\text { Identification }\end{array}$} & \multirow{3}{*}{$\begin{array}{l}\text { Risk Management } \\
\text { Objectives }\end{array}$} & \multirow{3}{*}{$\begin{array}{l}\text { Deriving } \\
\text { goals }\end{array}$} & Business Strategy & & \\
\hline & & & Manufacturing Strategy & & \\
\hline & & & Investment Strategy & & \\
\hline & \multirow{8}{*}{$\begin{array}{l}\text { Risks areas or } \\
\text { sources }\end{array}$} & \multirow{8}{*}{ Identifying } & $\mathrm{R} \& \mathrm{D}$ & & \\
\hline & & & Procurement & & \\
\hline & & & Production & & \\
\hline & & & Distribution & & \\
\hline & & & Sales \& Marketing & & \\
\hline & & & Investment Project Management & & \\
\hline & & & Strategic and Financial & & \\
\hline & & & External & & \\
\hline & Risk Profile & Compiling & Risk Register & & \\
\hline \multirow{5}{*}{$\begin{array}{l}\text { Risk } \\
\text { Assessment }\end{array}$} & \multirow{2}{*}{$\begin{array}{l}\text { Subjective } \\
\text { assessment }\end{array}$} & \multirow{5}{*}{ Measuring } & $\begin{array}{l}\text { Probability derived from experiences or } \\
\text { logic }\end{array}$ & & $\begin{array}{l}\text { (Macgill \& Siu, 2005; Merna \& Al-Thani, } \\
\text { 2005) }\end{array}$ \\
\hline & & & Impact derived from experiences or logic & & \\
\hline & \multirow{3}{*}{$\begin{array}{l}\text { Objective } \\
\text { Assessment }\end{array}$} & & Probability derived from historical data & & (Macgill \& Siu, 2005; Merna \& Al-Thani, \\
\hline & & & Impact derived from historical data & & \\
\hline & & & $\begin{array}{l}\text { Risk adjusted Net Present Value } \\
\text { Calculation }\end{array}$ & & $\begin{array}{l}\text { (Dixit, 1992; Hertz, 1979; Magni, 2002; Pratt \& } \\
\text { Hammond II, 1979; Trigeorgis, 2005) }\end{array}$ \\
\hline \multirow{3}{*}{$\begin{array}{l}\text { Risk } \\
\text { Administration }\end{array}$} & Risk Decision & \multirow{3}{*}{ Resolving } & Avoid - Reject or Postponed & & \\
\hline & & & Accept & & \\
\hline & Risk Mitigation & & Minimise & & \\
\hline \multirow{2}{*}{$\begin{array}{l}\text { Risk } \\
\text { Monitoring }\end{array}$} & Risk Indicator & \multirow[b]{2}{*}{ Reviewing } & Key risks & & \\
\hline & Periodic review & & $\begin{array}{l}\text { Continuous repetition of the risk } \\
\text { management process }\end{array}$ & & \\
\hline
\end{tabular}




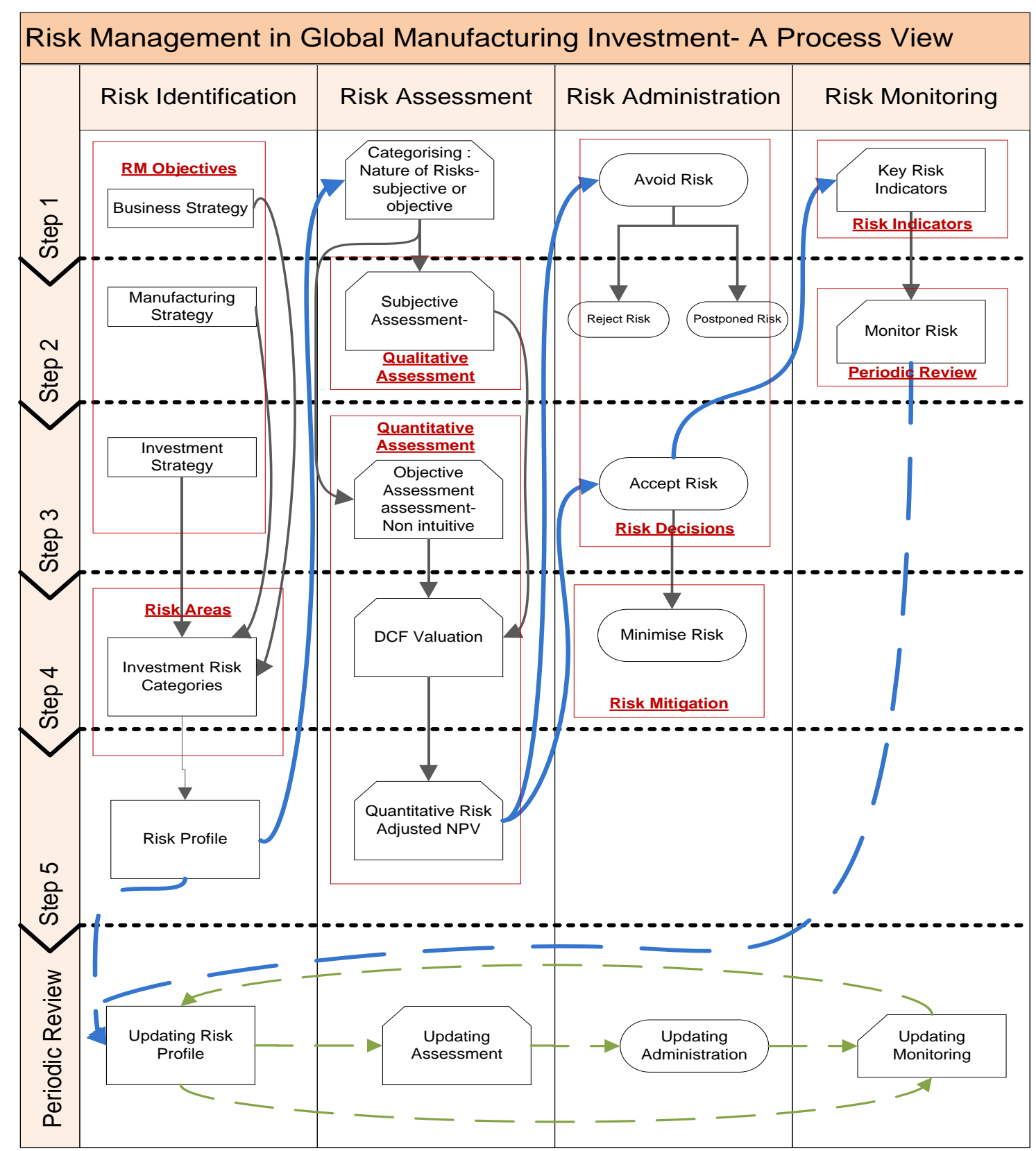

Figure 1: Proposed Plant investment risk management process 